УДК 343.2

DOI https://doi.org/10.32837/pyuv.v0i2(27).216

\author{
Г. М. Собко \\ кандидат юридичних наук, доцент, \\ професор кафедри кримінального права та кримінологї \\ факультету підготовки фахівиів для органів досудового розслідування \\ Одеського державного університету внутрішніх справ
}

\title{
РІЗНОВИДИ ПСИХІЧНОГО НАСИЛЬСТВА У ЗЛОЧИНАХ ПРОТИ ГРОМАДСЬКОЇ БЕЗПЕКИ
}

Особливої актуальності останнім часом набула боротьба із злочинами проти громадської безпеки. Ці злочини характеризуються специфічними ознаками: вони небезпечні для невизначено широкого кола громадських стосунків і посягають на основні цінності шляхом спричинення шкоди суспільно значимим інтересам. Іншими словами, подібними діяннями шкода може бути заподіяна різним інтересам - життю і здоров'ю особи, її правам і свободам, власності. Такі злочини вчиняються в поєднанні не тільки з фізичним насиллям, а й з психічним, яке своєю чергою заподіює реальну шкоду психічному здоров'ю широкого кола населення, породжує стрес, неспокій за свою безпеку, свободу вибору, як наслідок - лишається значний відбиток на житті та здоров'ї великої кількості людей. Тому дуже важливо, щоб норми закону щодо психічного насильства існували як засіб захисту на державному рівні громадянської безпеки - однієї із найвищих соціальних цінностей у державі. Наразі в законодавстві недостатній державний захист від такого виду насилля, адже громадська безпека захищена лише від погрози вбивством. Неможливо залишити рівень захисту громадської безпеки від психічного насилля в такому ж стані, який наразі закріплений в нормативно-правових актах. Слід проаналізувати це явище, зрозуміти, які $є$ різновиди психічного насилля у злочинах проти громадської безпеки, виявити їх специфічні риси та запропонувати шляхи удосконалення.

Тему різновидів психічного насильства у злочинах проти громадської безпеки досліджували такі вчені, як Ю.М. Антонян, П.В. Агапов, А.А. Абдульманов, Л.С. Белогриц-Котляревський, Л.Д. Гаухман, П.И. Гришаєв, С.У. Дикаєв, И-.Н. Данипін, В.К. Дуюнов, В.П. Емельянов, А.Н. Ігнатов, В.Н. Кудрявцев, В.С. Коміссаров, Н.М. Кропачев, А.И. Коробеєв, В.В. Лунєєв, Е.В. Лисенко, А.В. Наумов, Г.В. Овчиннікова, А.А. Піонтковський,С.В.Познишев, В.С.Прохоров, Б.Т.Разгильдиєв, Т.В. Сердюк, В.П. Тихий, Н.С. Таганцев, Н. Тарбагаєв, И.Я. Фойницький, Р.Д. Шарапов, М.Д. Шаргородський, С.С. Яценко та інші.

Для розкриття теми у статті необхідно дослідити поняття та сутність громадської безпеки та з'ясувати, які способи вчинення злочинів пов'язані з психічним насильством.
Перейдемо до аналізу поняття та сутності громадської безпеки.

Об'єктом кримінально-правової охорони потрібно вважати суспільні відносини, які охороняються кримінальним правом. Адже суспільні відносини виступають в ролі соціального зв'язку, соціального механізму, який не тільки набуває необхідної ваги в суспільстві за допомогою права, а й не може бути порушеним, бо охороняється нормами кримінального права. Саме встановлення та організація нормального, непорушного механізму функціонування суспільства і є основним завданням держави, яке вона виконує за допомогою права, з урахуванням його галузевих аспектів. Підтримуючи таку думку, В. Хвостов вважав, що злочин потрібно розглядати як діяння, яке підриває авторитет держави та права і тому має суспільний характер. Дослідження цього аспекту аналізованої проблеми дає змогу припустити, що суспільні відносини та правопорядок взаємопов'язані між собою. Суспільні відносини є змістом, а закріплення їх у правовій формі - правопорядком, тобто зовнішньою формою існування таких відносин у конкретному суспільстві $[1$, с. 104-105].

Під громадянською безпекою розуміємо дотримання громадянських прав і свобод, закріплених у міжнародних документах, Конституціях і інших нормативних приписах, які встановлюють межі видів діяльності, громадян, що порушують безпеку, по найбільш важливим параметрам життєдіяльності, що дають можливість інтегруватися в суспільство, розвивати потенціал адаптивної гнучкості (готовності до змін) і зберігати людську гідність. Це поняття робить чіткішими предмет соціального захисту і критерії оцінки діяльності держави, соціальних інститутів і інших соціальних суб'єктів, що впливають на рівень безпеки громадян в суспільстві. Крім того, воно сприяє обмеженню свавілля держави в одноосібній розробці політики безпеки і діяльності соціальних інститутів по реалізації відповідних заходів, а також заходів контролю за виконанням цих заходів [2, c. 120].

Громадська безпека в найширшому розумінні - стан захищеності життєво важливих інтересів держави, суспільства, особи. Громадська безпека - це необхідний і достатній рівень правової 
захищеності інтересів суспільства, що забезпечує безпечні умови його існування.

Громадська безпека розуміється як певна сукупність суспільних відносин, що забезпечують захищеність суспільства та окремих йото громадян від загально небезпечних загроз. Громадська безпека, за В.С. Комісаровим, являє собою певну сукупність суспільних відносин, не лише регулюючих безпечні умови життя суспільства, а й підтримуючих такий рівень захищеності суспільства, який є достатнім для його нормального функціонування [3, с. 8].

Безпека суспільства означає захист його матеріальних і духовних цінностей від зовнішніх i внутрішніх загроз, а також передбачає наявність суспільних інститутів, правових норм, розвинутих форм суспільної свідомості, що гарантують реалізацію і захист цих умов.

Про громадську безпеку як самостійне, системне поняття слід говорити не лише тоді, коли порушується спеціальна безпека, зумовлена підвищено-небезпечними властивостями окремих виробництв або предметів, але і коли йдеться про загальні правила безпеки, прийняті в суспільстві. При цьому під загальними правилами безпеки розуміються встановлені в цілях попередження насильницьких способів вирішення соціальних конфліктів правила поведінки, які обов'язкові для усіх членів суспільства і якими вони зобов'язані керуватися в усіх сферах життєдіяльності.

Характерними істотними ознаками громадської безпеки є:

- забезпечення безпеки невизначеного кола інтересів, що охороняються правом (особи, майна, діяльності соціальних інститутів і так далі);

- забезпечення недоторканості життя і здоров'я особи;

- комплексний характер, що дозволяє забезпечувати охорону інших соціальних благ;

- тісний взаємозв'язок і взаємозалежність складових елементів.

У кримінальному праві громадська безпека як об'єкт кримінально-правової охорони в найбільш загальному вигляді є певною сукупністю громадських відносин, у рамках якої забезпечуються безпечні умови життя суспільства. У цьому сенсі вона являється не лише однією з потреб суспільства, але і загальним благом, загальною цінністю, у збереженні і розвитку яких зацікавлені і держава, і суспільство, і громадяни. Головну відповідальність за стан безпеки в суспільстві несе насамперед держава. Саме вона формує систему забезпечення громадської безпеки, під якою слід розуміти сукупність заходів політичного, правового, економічного, організаційного, науково-технічного та іншого характеру. Ця система має своїм основним завданням підтримку соціально прийнятного рівня. Вона включає правові, техно- логічні й організаційні норми, а також спеціальні правила безпеки.

Сутність громадської безпеки полягає у їі соціальній функції: відбиваючись в громадській психології, суспільній свідомості, громадська безпека асоціюється з певним рівнем упевненості громадян суспільства в захищеності суспільства і конкретного громадянина від суспільно небезпечних посягань, недоторканості основних соціальних благ суспільства. Чим більш реальні зусилля суспільства і держави по забезпеченню системи громадської безпеки, тим впевненіше почувають себе громадяни в процесі вступу в різні соціальні зв'язки.

Засобом забезпечення громадської безпеки як захищеності є дотримання (чи чіткий орієнтир на дотримання) принципу соціальної справедливості, що реалізовується в усіх сферах життєдіяльності людей. Зрозуміло, що покладання надії на соціальну справедливість як на ідеальну (і недосяжну) цінність не може принести позитивних результатів. Але у своєму операційному значенні це поняття цілком придатне для громадських практик, оскільки соціальна справедливість - це ніби міра громадської користі (соціальної адекватності) законів і інших нормативних приписів (формальних і неформальних, офіційних і неофіційних), що встановлюють і підтримують на основі угоди такий порядок життєдіяльності людей i організацій, фізичних і юридичних осіб, який сприяє виживанню і розвитку соціуму, забезпечує інтеграцію і гідне існування його членів. У цьому інструментальному визначенні зафіксовані орієнтири (цілі), а також засоби їх досягнення. Соціально справедливі такі форми правління, норми, закони i діяльність соціальних інститутів, які на основі угоди створюють і підтримують основи гідного життя людей, забезпечуючи тим самим громадську безпеку. Під виразом «гідне існування» мається на увазі узагальнення усіх тих прав, свобод і цінностей, які проголошуються у сучасному суспільстві: міра рівності і свободи, соціальна підтримка, рівень освіти, включеність у соціальні мережі, широкі можливості вибору легальних видів діяльності, захист людської гідності і так далі [2, с. 123$]$.

Насильницький злочин проти громадської безпеки - це усвідомлено здійснене громадське небезпечне діяння, що насильно змінює суспільну свідомість у частині життя, здоров'я, особистої недоторканості відносно безпечних умов існування суспільства, за яке встановлена кримінальна відповідальність.

Виділяють такі різновиди психічного насильства у злочинах проти громадської безпеки: залякування населення, примушування та погроза.

Залякування населення - це висловлення та демонстрація таких дій, що спричиняють хаос 
в суспільстві, породжують паніку, страх за своє життя та здоров'я, а також за життя та здоров'я близьких людей. Наприклад, залякування населення підривом аеропорту.

Примушування - це стимуляція людини до виконання певних дій за допомогою погроз (відкритих або таких, що маються на увазі) або поневірянь. Примушування можливе тільки у тому випадку, якщо той, що змушує, дійсно має можливості реалізації погроз, тобто повноваження в позбавленні адресата яких-небудь благ або в зміні умов його життя і роботи. Такі можливості можна назвати контролюючими. Змушуючи, ініціатор погрожує застосуванням своїх контролюючих можливостей для того, щоб добитися від адресата потрібної йому поведінки. У найбільш грубих формах примусу можуть використовуватися погрози фізичної розправи. Суб'єктивно примус сприймається як тиск: ініціатором - як власний тиск, адресатом - як тиск на нього з боку ініціатора або обставин. Наприклад, примушування до вступу в злочинну організацію погрозою вбивством.

Отже, проаналізувавши поняття та сутність громадської безпеки, можна відмітити їі важливість та цінність як об’єкту кримінально-правової охорони.

Отже, враховуючи все вищезазначене, можемо дійти таких висновків:

1. Громадська безпека розуміється як певна сукупність суспільних відносин, що забезпечують захищеність суспільства та окремих його громадян від загально небезпечних загроз.

2. Сутність громадської безпеки полягає у їі соціальній функції: відбиваючись у громадській психології, суспільній свідомості, громадська безпека асоціюється з певним рівнем впевненості громадян суспільства в захищеності суспільства і конкретного громадянина від суспільно небезпечних посягань, недоторканості основних соціальних благ суспільства. Чим більш реальні зусилля суспільства і держави по забезпеченню системи громадської безпеки, тим впевненіше почувають себе громадяни в процесі вступу в різні соціальні зв'язки.

\section{Jimepamypa}

1. Стрельцов Є. Проблеми встановлення соціально-правової шкоди від злочину. Право України. 2011. № 9. с. 104-105.

2. Шипунова Т.В. Гражданская безопасность и насилие. Социологические исследования. № 6, 2016.150 с.

3. Российское уголовное право : курс лекций. Т. 5. Преступления против общественной безопасности и общественного порядка / Под ред. А.И Коробеева. Владивосток : Изд-во Дальневост. ун-та, 2001. 592 с.

\section{Анотація}

Собко Г. М. Різновиди психічного насильства у злочинах проти громадської безпеки. - Стаття.

Громадська безпека в найширшому розумінні - стан захищеності життєво важливих інтересів держави, суспільства, особи. Громадська безпека - це необхідний і достатній рівень правової захищеності інтересів суспільства, що забезпечує безпечні умови його існування.

Під громадянською безпекою розуміємо дотримання громадянських прав і свобод, закріплених в міжнародних документах, Конституціях і інших нормативних приписах, які встановлюють межі видів діяльності, громадян, що порушують безпеку, по найбільш важливим параметрам життєдіяльності, що дають можливість інтегруватися в суспільство, розвивати потенціал адаптивної гнучкості (готовності до змін) і зберігати людську гідність. Це поняття робить чіткішими предмет соціального захисту і критерії оцінки діяльності держави, соціальних інститутів і інших соціальних суб'єктів, що впливають на рівень безпеки громадян в суспільстві. Крім того, воно сприяє обмеженню свавілля держави в одноосібній розробці політики безпеки і діяльності соціальних інститутів по реалізації відповідних заходів, а також заходів контролю за виконанням цих заходів.

Суспільні відносини виступають в ролі соціального зв'язку, соціального механізму, який не тільки набуває необхідної ваги в суспільстві за допомогою права, а й не може бути порушеним, бо охороняється нормами кримінального права. Саме встановлення та організація нормального, непорушного механізму функціонування суспільства і є основним завданням держави, яке вона виконує за допомогою права, з урахуванням його галузевих аспектів. Підтримуючи цю думку, В. Хвостов вважав, що злочин потрібно розглядати як діяння, яке підриває авторитет держави та права i тому має суспільний характер. Дослідження цього аспекту аналізованої проблеми дає змогу припустити, що суспільні відносини та правопорядок взаємопов'язані між собою. Суспільні відносини є змістом, а закріплення їх у правовій формі - правопорядком, тобто зовнішньою формою існування таких відносин у конкретному суспільстві.

Ключовіслова:громадськабезпека, психічненасильство, насильство, організована злочинність, напад.

\section{Summary}

Sobko G. M. Mental violence in public safety crimes. Article.

Public safety in the broadest sense is a state of protection of vital interests of the state, society, and the individual. Public safety is a necessary and sufficient level of legal protection of the interests of society, which ensures safe conditions for its existence.

By civil security we mean the observance of civil rights and freedoms enshrined in international instruments, constitutions and other regulations that set the boundaries of activities, citizens who violate security, by the most important parameters of life, enabling to integrate into the society, to develop the potential of adaptive (readiness for change) and maintain human dignity. This concept makes the subject of social protection more clear and the criteria for evaluating the activities of the state, social institutions and other social actors that affect the level of security of citizens in society. In addition, it helps to limit the arbitrariness of the state in the sole development of a policy of security and activities of social institutions to implement appropriate measures, as well as measures to monitor the implementation of these measures.

Social relations act as a social bond, a social mechanism that not only gains the necessary weight in society through law, but cannot be violated because it is protected by criminal law. It is the establishment and organization 
of a normal, unbreakable mechanism of functioning of society and is the main task of the state, which it performs through the law, taking into account its sectoral aspects. In support of this opinion, V. Khvostov believed that crime should be considered as an act that undermines the authority of the state and law and therefore has a public character. A study of this aspect of the problem under analysis suggests that public relations and the rule of law are interrelated. Public relations are the content, and their fixing in the legal form is the rule of law, that is, the external form of the existence of such relations in a particular society.

Key words: public safety, mental violence, violence, organized crime, assault. 